Journal of the Sedimentological Society of Japan 堆積学研究

Vol. 70, No. 1, p. 43-47 (2011)

\title{
西南日本宮古島の更新統浅海成炭酸塩岩における 地表露出面の認定と相対的海水準変動
}

\author{
南條 貴志 ${ }^{*} \cdot$ 溝田 あゆみ**・松田 博貴*
}

\section{Recognition of subaerial exposure surface and relative sea-level change in Pleistocene shallow-marine carbonates in the southern part of Miyako Island, southwestern Japan}

\author{
Takashi Nanjo $^{1 *}$, Ayumi Mizota ${ }^{* *}$ and Hiroki Matsuda*
}

The Pleistocene Ryukyu Group composed mainly of shallow-marine carbonates was deposited with highamplitude and short-termed glacioeustatic sea-level changes in the Middle Pleistocene age. We carried out core observation, carbon and oxygen isotopic analyses and XRD analyses to recognize subaerially exposure surfaces (SES), and to make clear the precise sea-level changes in the Middle Pleistocene age. For the purpose, six boring cores in the southern part of Miyako Island, southwestern Japan, were examined. As a result, the followings are revealed; (1) the Ryukyu Group of the study area is divided into 6 units, (2) each unit can be subdivided into two to four subunits based on SES, (3) each subunit was deposited during the interstadial period such as $5 \mathrm{a}, 5 \mathrm{c}$ and $5 \mathrm{e}$ during the Marine Oxygen Isotope Stage 5.

Key words: carbon and oxygen isotope, sea-level change, subaerial exposure surface

はじめに

第四紀更新統琉球層群は, 高振幅 ・短周期の海水準変動 の影響を受け堆積した. 宮古島における琉球層群には, 水 深 0〜 50 m 程度の浅海域での堆積を示す堆積相が含まれ, 海水準変動の振幅が $100 \mathrm{~m}$ を超える第四紀において, これ らの堆積物が整合一連に堆積したと考えるのは難しく, し ばしば地表に露出したと考えられる，しかしながら, 琉球

受付: 2011 年 1 月 12 日 受理 : 2011 年 6 月 3 日

* 熊本大学大学院自然科学研究科

Graduate School of Science and Technology, Kumamoto University, Kumamoto, 860-8555, Japan

*** 熊本大学大学院自然科学研究科 (現日本海洋事業株式会 社)

Graduate School of Science and Technology, Kumamoto University (Presently Nippon Marine Enterprises, Ltd.)

1 Corresponding author : Takashi Nanjo,096d9008@st.kumamotou.ac.jp
層群において地表露出を示す古土壤層やカルクリート組織 などは, 一部を除き保存状態が悪く, 露頭観察やコア観察 などで詳細な層序や海水準変動を復元することは難しい. Allan and Mathews（1982）は，炭素・酸素同位体組成を用い ることで地表露出面を認定できることを提唱し, 炭素同位 体組成が地表露出面直下で 2 4\%の負のシフトを示し, 下 位に向け次第に重い值に変化するなどのシグナルが認めら れれば，地表露出面を認定できるとした，彼らのモデルの 利点は, 古土壤層やカルクリート組織などが, 風化や後の 海進に伴い削剥されてしまった場合でも，炭素・酸素同位 体組成のシグナルが残されていれば地表露出面を認定でき るところにある。つまり, 地表露出に関連した組織の保存 状態が悪い琉球層群において有用性が高いと考えられる (松田, 1995). そこで本研究では, 沖縄県宮古島南部で掘 削された 6 本のボーリングコアを用いて，炭素・酸素同位 体組成に基づいて地表露出面を認定し, 詳細な海水準変動 を復元することを目的として研究を行った。 


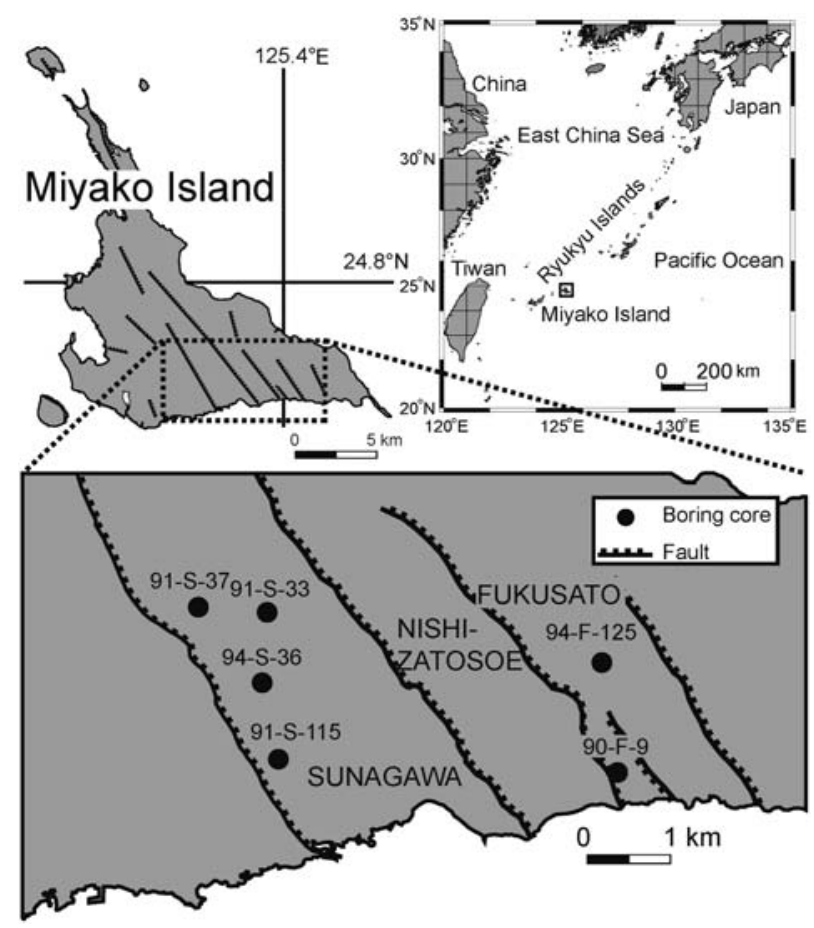

Fig. 1 Geographic map of study area. For descriptive purpose, it is divided into three areas; Sunagawa, Nishizatosoe, Fukusato, bounded by normal fault.

\section{調查地域・手法}

沖縄県宮古島は, 沖縄本島南西約 $300 \mathrm{~km}$ に位置し, 三角 形の形状を呈する島であり，島全域に更新統琉球層群が分 布する. 研究地域は, 島の南部に位置し (Fig. 1), 複数の正 断層により, 西から砂川地域, 西里添地域, ならびに福里 地域の 3 地域に分けられる. 本地域の琉球層群は, サンゴ 石灰岩相, 石灰藻球石灰岩相, 生砕性石灰岩相, 大型有孔 虫石灰岩相，ならびに石灰質砂/砂/シルト相の 5 つの岩相 に区分される。一回の海水準変動で堆積した堆積物を 1 つ のユニットとすると, 琉球層群は岩相とサンゴ群集に基づ き7つのユニット（ユニット1７）に区分される，その堆 積時には, 東側の福里地域の標高は, 西側の砂川地域と比 べて, $60 \mathrm{~m}$ 以上高かったと推定される（溝田・松田, 2004). さらに堆積時代は, 石灰質ナンノ化石と古地磁気層序から, 0.95 0.41 Ma である（松井ほか, 2002 ; 山田・松田, 2002 ; 溝田・松田, 2004).

本研究では, 砂川地域で 4 本 (91-S-37, 91-S-33, 94-S36, 91-S-115), 福里地域で 2 本 (94-F-125, 90-F-9) のボー リングコアを用いて研究を行った，1/10 スケールの柱状図 を作成し, 岩相とサンゴ群集を基にユニット区分を行った。
分析用試料は $0.5 \sim 1 \mathrm{~m}$ 間隔で，できる限り基質から採取 し，鉄乳鉢とメノウ乳鉢を用いて粉末試料とした．試料数 は 273 である. その後, X線回折分析ならびに炭素・酸素 同位体分析を行い，炭酸塩鉱物組成と炭素・酸素同位体組 成を求めた。な扮本研究では, 本地域に分布するユニット 1〜7のうち, ボーリングコア中に認められるユニット $1 \sim 6$ を対象とした.

\section{結果ならびに考察}

コア試料の炭酸塩釷物は, すべて低 $\mathrm{Mg}$ 方解石からなる. また炭素同位体組成は, $-0.9 \sim-8.3 \% 0 \delta^{13} \mathrm{C}_{\mathrm{PDB}}$ を示し, 酸 素同位体組成は, $-3.4 \sim-6.3 \% \delta^{18} \mathrm{O}_{\mathrm{PDB}}$ を示す (Figs. 2 and 3).すべての試料が低 $\mathrm{Mg}$ 方解石のみからなること, 変動 幅の大きい炭素同位体組成と変動幅の小さい酸素同位体組 成に特徵づけられることから, 本研究地域の琉球層群は広 く淡水性続成作用を被っていると考えられる。炭素同位体 組成は, 各ユニット境界の直下で 1 6\% $\%$ の負方向へのシフ 卜を示し，下位に向け次第に重い值に変化することが認め られ，しばしばカルクリート組織も観察される。これは, Allan and Mathews（1982）に打ける地表露出面を認定する シグナルを明瞭に示しており, 本研究地域の琉球層群にお いても，炭素・酸素同位体組成を用いた地表露出面の認定 は有効であることが示唆される，さらに各ユニットの内部 においても, 炭素同位体組成の負のシフトが複数認められ る.これらはユニット境界直下と同様の挙動を示すため, 各ユニット内部でも炭素同位体組成の負のシフトが確認さ れた層準では, 地表露出の可能性が指摘される.

上記に基づき検討した結果, ユニット境界を含め, ユニッ 卜 1 ～3, ならびに 5 で最大 4 層準, ユニット 4 で 2 層準の 地表露出面が認められる。 ユニット 6 では, 上限は不明で あり, 地表露出面は認められない (Figs. 2 and 3). 本研究で は, 各ユニット内の地表露出面から次の地表露出面までの 一連の堆積物をサブユニットとして定義し, 地表露出面の 層準, 岩相, サンゴ群集, ならびにコアの標高を基に, 各地 表露出面の対応関係を検討した，その結果，ユニット 1〜3, ならびに 5 は 4 つのサブユニットに, ユニット 4 は 2 つの サブユニットに区分される.

各ユニットの堆積時代は, ユニット 4 の下位でブリュン ヌーマッヤマ古地磁気境界 $(0.78 \mathrm{Ma})$ が確認されているこ と（松井ほか, 2002), $1.045 \pm 0.025 \mathrm{Ma}$ の初産出面をもつ Gephylocapsa parallela がユニット 1〜3で産出すること（山 田・松田，2002）から，ユニット 1〜3は $1.045 \sim 0.78 \mathrm{Ma}$ の 間に堆積したと考えられる (Fig. 4)。宮古島近隣の伊良部 島に扔いて, $0.55 \mathrm{Ma}$ を境に, 琉球層群の発達様式がリトロ グラデーショナルないしアデグラデーショナルな発達様式 


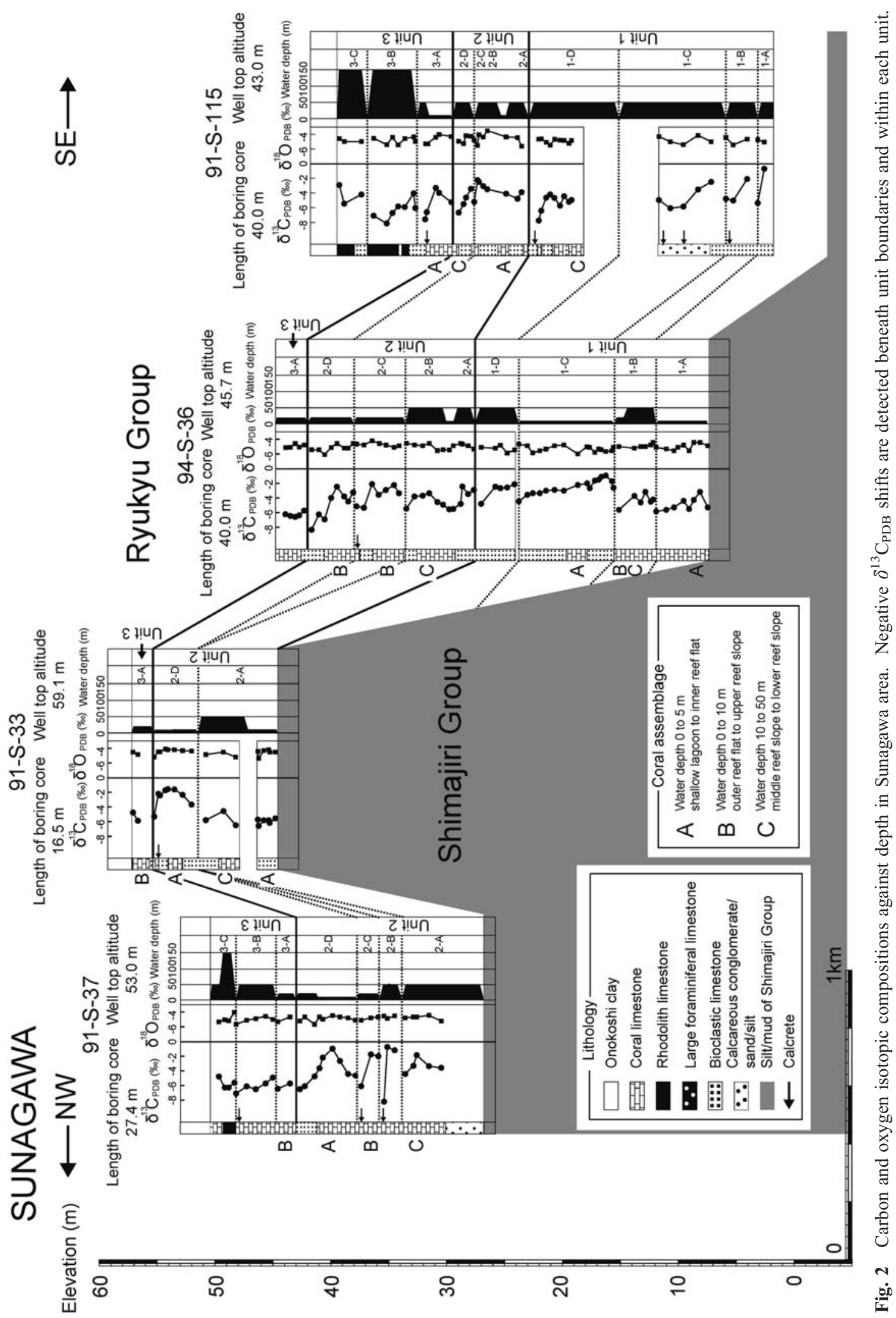




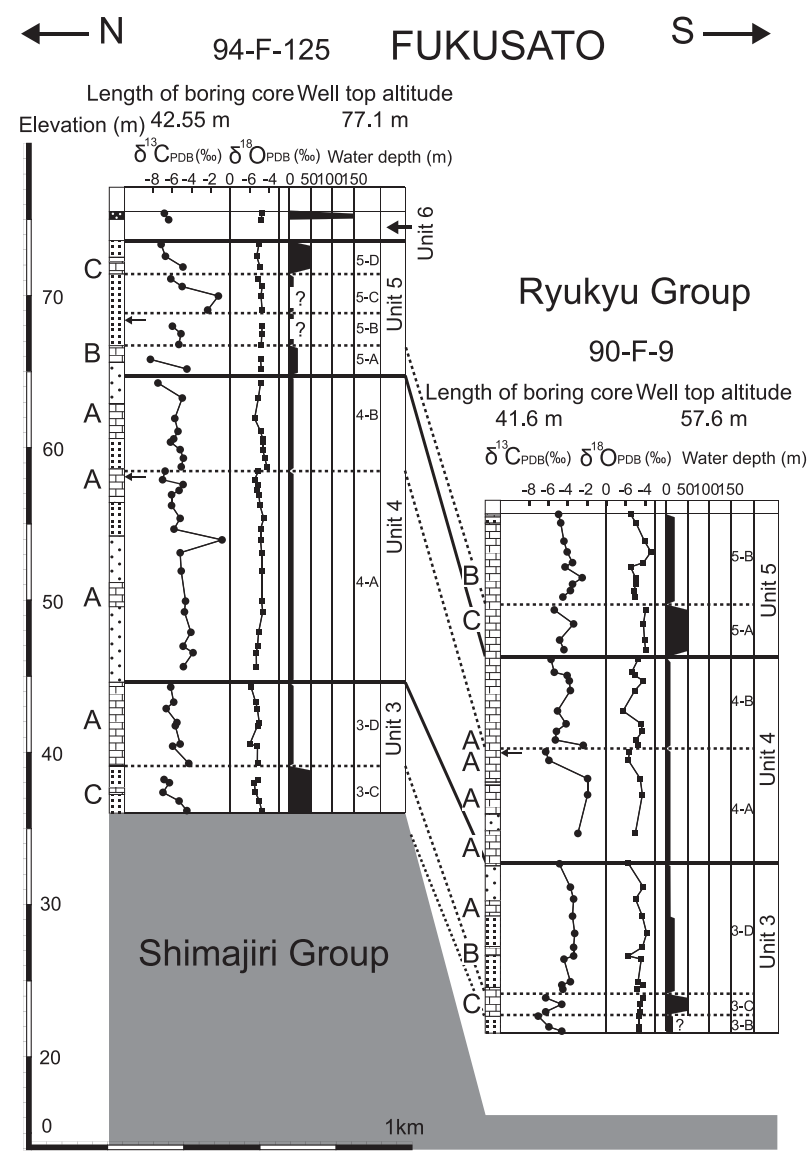

Fig. 3 Carbon and oxygen isotopic compositions against depth in Fukusato area. Legend is shown in Fig. 2. Negative $\delta^{13} \mathrm{C}_{\mathrm{PDB}}$ shifts are detected beneath unit boundaries and within each unit as same as Sunagawa area.

からオフラップ型の発達様式へ変化したこと (Sagawa et al., 2001), ならびに本研究地域においてオフラップ型の発達 様式は認められないことから，ユニット $4 \sim 6$ は $0.78 \sim 0.55$ Maの間に堆積したと考えられる.

Berger et al.（1994）における浮遊性有孔虫を用いた酸素 同位体曲線では，ユニット 1 ～3 が堆積した $1.045 〜 0.78 \mathrm{Ma}$ の間に MIS（海洋酸素同位体ステージ）27，25，23，19の 4 つの間水期が，ユニット $4 \sim 6$ が堆積した $0.78 〜 0.55 \mathrm{Ma}$ の間には $19,17,15$ の 3 つの間水期が存在する。したがっ てユニット 4 の下位が $0.78 \mathrm{Ma}$ であることから，ユニット 1 は水期で低海水準期である MIS28 から MIS24 までに堆 積し, 同様にユニット 2 は MIS24～22, ユニット 3 は MIS22 ～20, ユニット 4 は MIS20～18, ユニット 5 は MIS18～16, ユニット 6 は MIS16〜14 の相対的海水準変動に対応して 堆積したと推定され, 各ユニットは約 10 万年周期の海水
準変動に対応していると考えられる。したがって，本研究 で明らかにされた各ユニット内のサブユニットはさらに短 周期の相対的海水準変動に対応して堆積されたことが指摘 される.

さらに岩相, サンゴ群集および地表露出面により, 各ユ ニット内における相対的な海水準は, ユニット 1 と 2 では 水深 $0 \sim 50 \mathrm{~m}$ の範囲で変動し，ユニット $3 \sim 6$ では水深 0〜 $150 \mathrm{~m}$ の範囲で変動している. また各サブユニット内 における相対的な海水準は，岩相とサンゴ群集により，ほ とんどが水深 0〜 $50 \mathrm{~m}$ の範囲で変動したと考えられる。 た だし, 砂川地域の 91-S-115 では, 石灰藻球石灰岩相中に地 表露出面の存在が指摘されることから, サブユニット3-B と 3-C の相対的な海水準は水深 $0 \sim 150 \mathrm{~m}$ の範囲で変動し たと考えられる。

琉球層群が堆積した当時, 本研究地域は徐々に沈降して いたことが指摘されていることから（山田, 2002), 沈降速 度を一定として, 岩相とサンゴ群集から中部更新世の海水 準変動を復元し, 酸素同位体曲線（Berger et al., 1994）と比 較 (Fig. 4) すると, 本研究で得られたサブユニットに対応 する小規模な海水準変動は, 酸素同位体曲線の約 10 万年 周期の海水準変動中に見られる亜水期 - 亜間水期のサイク ルと非常によい相関を示す. 特にユニット 1 と 3〜 5 につ いては, 酸素同位体ステージ内に認められる亜間水期の数 とサブユニットの数が一致する。この結果は, 地表露出面 が亜水期に形成されたことを支持し，本研究地域において 地表露出面から求められたサブユニットは, 亜間水期にお ける堆積に対応している可能性が指摘される。

以上のことから，炭素・酸素同位体組成を用いた地表露 出面の認定は, 水期 - 間水期サイクルよりも短周期の亜水 期・亜間水期などの海水準変動まで求められる可能性があ る。 


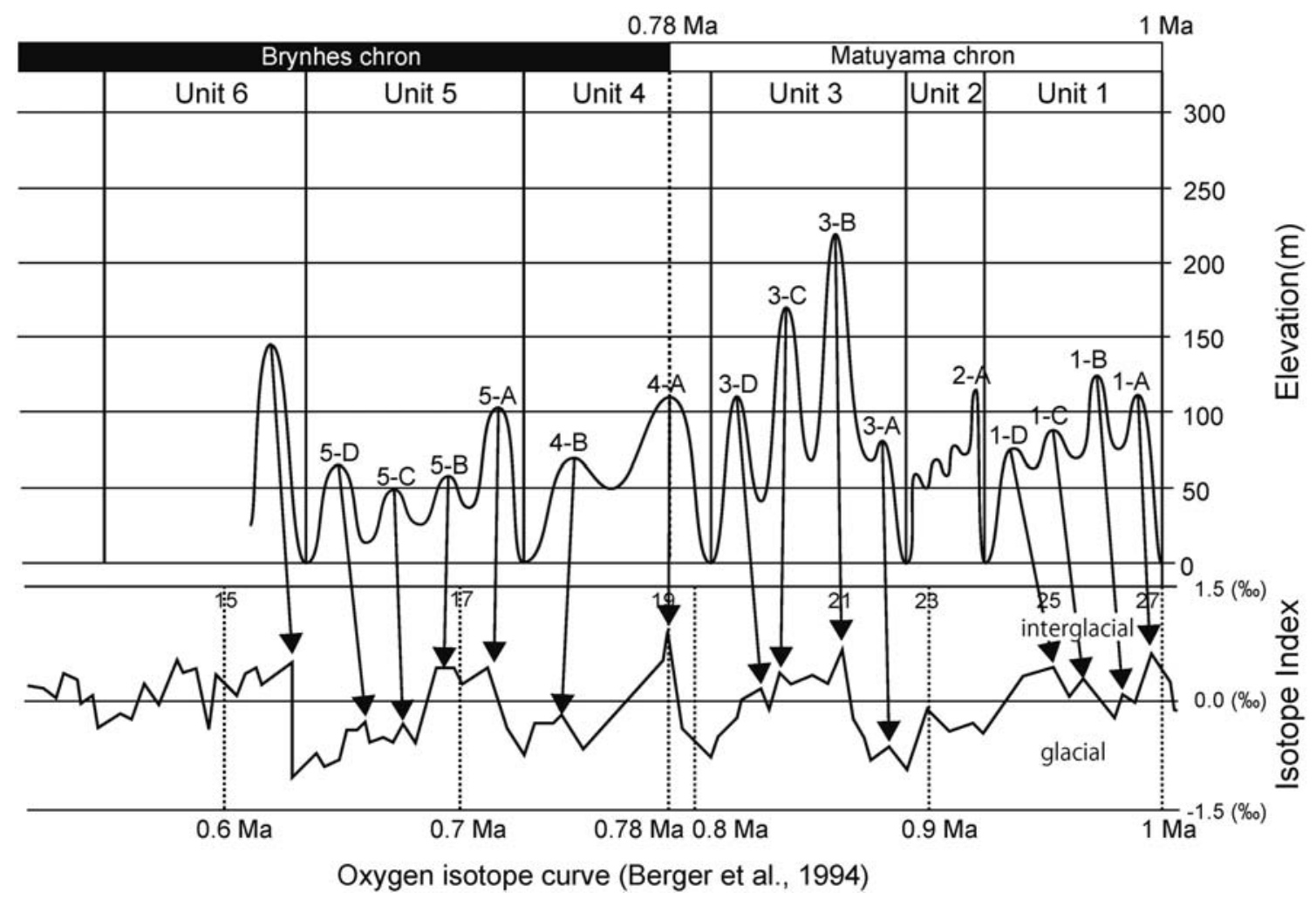

Fig. 4 The sea-level change curve in the Middle Pleistocene. The upper curve shows the sea-level change in this study and the lower curve indicates the oxygen isotope curve (Berger et al., 1994).

\section{文献}

Allan, J.R. and Mathews, P.K., 1982, Isotope signatures associated with early meteoric diagensis. Sedimentology, 29, 797-817.

Berger, W.H., Yasuda, M.K., Bickert, T., Wefer, G. and Takayama, T., 1994, Quaternary time scale for the Ontong Java Plateau: Milankovitch template for Ocean Drilling program site 806. Geology, 22, 463-467.

松田博貴, 1995, 浅海成炭酸塩岩シーケンスにおける炭素・酸素 安定同位体組成に基づく地表露出面の認定. 地質雑, 101, 889-901.

松井千里, 山田茂昭, 松田博貴, 渋谷秀敏, 2002, 礁性石灰岩の 古地磁気層序の試み一沖縄県宮古島の琉球層群を例として
一. 第 112 回日本地球電磁気 - 地球惑星圈学会要旨, 193 . 溝田あゆ久, 松田博貴, 2004, 沖縄県宮古島南部における琉球層 群の層序とサンゴ礁発達史. 第 24 回炭酸塩コロキウム講演 要旨, 16 .

Sagawa, N., Nakamori, T. and Iryu, Y., 2001, Pleistocene reef development in the southwest Ryukyu Islands, Japan. Paleogeography, Plaleoclimatology, Palaeoecology, 20, 303-323.

山田茂昭, 松田博貴, 2002, 第四系琉球層群の成立過程一琉球列 島における古サンゴ礁の変遷一．第 22 回炭酸塩コロキウム 講演要旨, 41 .

山田茂昭, 2002, 更新世における南琉球弧のサンゴ礁の発達史と 構造運動. 熊本大学博士論文, $277 \mathrm{p}$. 